A N N A LE S

UNIVER S T A T IS MARIAE CURIE-SKŁODOW S A LUBLIN - POLONIA

VOL. XXX, 1

SECTIO J

2017

Uniwersytet Marii Curie-Skłodowskiej w Lublinie. Wydział Pedagogiki i Psychologii

\title{
ANNA WIATROWSKA
}

anna.wiatrowska@umcs.pl

\section{Poczucie koherencji a wartości podstawowe u kobiet $z$ anoreksja $i$ bulimia psychiczna}

The Sense of Coherence and Basic Values in Women with Anorexia and Bulimia Nervosa

\section{STRESZCZENIE}

Zasadniczym celem podjętych badań było poszukiwanie zależności między poczuciem koherencji i jego wymiarami a wartościami podstawowymi u kobiet $\mathrm{z}$ zaburzeniami odżywiania. W badaniu wykorzystano Portretowy Kwestionariusz Wartości (PVQ-R2) Schwartza oraz Kwestionariusz Orientacji Życiowej (SOC-29) Antonovsky’ego. Badaniami objęto 40 kobiet z anorexia nervosa oraz 40 z bulimia nervosa według kryteriów badawczych ICD-10. Istotne statystycznie różnice wystąpiły w poczuciu koherencji i hierarchii wartości podstawowych u kobiet $\mathrm{z}$ anoreksją i bulimią oraz w strukturze powiązań między nimi. Uzyskane wyniki potwierdzają zasadność dokonanego zróżnicowania badanych kobiet ze względu na postać zaburzeń odżywiania. Znajomość hierarchii wartości u kobiet z zaburzeniami odżywiania może mieć istotne znaczenie w wyjaśnianiu ogólnych zasobów odpornościowych i możliwości adaptacyjnych.

Słowa kluczowe: poczucie koherencji; wartości podstawowe; anoreksja psychiczna; bulimia psychiczna

\section{WPROWADZENIE}

Jadłowstręt psychiczny (anorexia nervosa) i bulimia psychiczna (bulimia nervosa) są klasyfikowane jako jednostki chorobowe o podłożu psychicznym. Charakteryzują się one niewłaściwymi nawykami i postawami wobec jedzenia oraz przyjmowania pokarmów, zaburzoną percepcją wagi ciała i proporcji sylwet- 
ki, a także nieprawidłowymi zachowaniami kompensacyjnymi służącymi utracie masy ciała i nieprzybraniu na wadze (Kreipe, Dukarm 2000; zob. Wiatrowska 2009). Rozpowszechnienie anoreksji psychicznej w populacji, według różnych danych, waha się od 0,5\% do 4\% (Dunajska, Rabe-Jabłońska 2004; Woronowicz 2009), a zagrożenie chorobą sięga do 30\% (Sołtysiak, Sudar-Malukiewicz 2003). Występowanie bulimii jest nieco większe od anoreksji. Ocenia się je na około od $1,1 \%$ do $4,2 \%$, a na poziomie subklinicznym nawet do $10 \%$ (Namysłowska 2002; Rabe-Jabłońska 2003).

Anoreksję charakteryzuje stałe i znaczne ograniczenie przyjmowania pokarmów (zwłaszcza bogatych w tłuszcze), często w połączeniu z różnorodnymi formami zachowań (ćwiczenia fizyczne, wymioty, nadużywanie środków przeczyszczających lub moczopędnych itp.), które służą utracie wagi lub uniknięciu przybrania na wadze (Kreipe, Dukarm 2000; zob. Wiatrowska 2009). Zaprzestaniu przyjmowania jedzenia często towarzyszy brak łaknienia oraz intensywny lęk przed przyrostem wagi ciała, będący kolejnym kryterium diagnostycznym anoreksji.

Bulimia psychiczna charakteryzuje się jedzeniem dużych ilości pokarmów w krótkim okresie i w niekontrolowany sposób. Napadom jedzenia towarzyszą zachowania kompensacyjne służące uwolnieniu ciała od skutków spożytej energii i nieprzybraniu na wadze (Kreipe, Dukarm 2000; zob. Wiatrowska 2009). Aby można było mówić o bulimii, epizody objadania się wraz z zachowaniami kompensacyjnymi muszą występować przynajmniej dwa razy w tygodniu przez okres co najmniej 3 miesięcy. Początki bulimii mogą być związane nie tylko z kontrolowaniem wagi ciała, ale i z innymi wydarzeniami, takimi jak kryzysy w życiu rodzinnym, śmierć kogoś bliskiego, stres egzaminacyjny czy zmiana pracy (Abraham, Llewellyn-Jones 2004).

Etiologia zaburzeń jedzenia jest złożona i wieloczynnikowa. Wśród czynników, które mogą mieć znaczenie dla wystąpienia objawów anoreksji i bulimii psychicznej, wymienia się biologiczne, indywidualne, rodzinne i społeczno-kulturowe. W przebiegu choroby, zależnie od fazy i stopnia wyniszczenia, występują liczne zaburzenia somatyczne związane z różnym ryzykiem zagrożenia życia czy też powstania trwałych zmian w funkcjonowaniu wielu narządów. Poważne zaburzenia metaboliczne obserwuje się zwłaszcza u chorych, u których w ciągu kilku miesięcy nastąpił znaczny ubytek masy ciała, a przede wszystkim u tych, którzy często prowokowali wymioty lub często przyjmowali środki przeczyszczające i/lub odwadniające (Rabe-Jabłońska i in. 2008).

Zdaniem Antonovsky'ego (2005) zasadniczą rolę w genezie zdrowia odgrywa koncepcja poczucia koherencji. Jest ono zdaniem tego badacza trwałym nastawieniem, które decyduje o tym, jak świat jest postrzegany, odczuwany i rozumiany przez konkretnego człowieka. Silne poczucie koherencji sprawia, że człowiek uruchamia właściwe dla danej sytuacji zasoby i potrafi je w pełni wykorzystać. 
W kształtowaniu się poczucia koherencji istotną rolę odgrywają z jednej strony zgeneralizowane zasoby odpornościowe (w tym odporność fizyczna, biochemiczna organizmu, wykształcenie, pozycja zawodowa, możliwości intelektualne, zdolności interpersonalne), a z drugiej doświadczenia życiowe osadzone w kontekście społeczno-kulturowym i polityczno-ekonomicznym (Sęk 2001). Czynnikiem o charakterze bezpośredniego oddziaływania jest rodzina i przyjmowane w niej wzorce zachowania.

Poczucie koherencji zawiera trzy skorelowane ze sobą wymiary: poczucie zrozumiałości, poczucie zaradności i poczucie sensowności. Poczucie zrozumiałości, jak podkreśla Antonovsky (2005), odnosi się do stopnia, w jakim człowiek postrzega bodźce, napływające ze środowiska wewnętrznego i zewnętrznego, jako sensowne poznawczo, uporządkowane, spójne, ustrukturalizowane i jasne, a nie informacje chaotyczne, nieuporządkowane, losowe, przypadkowe czy niewytłumaczalne. Poczucie zaradności określa stopień, w jakim człowiek postrzega dostępne środki (własne, należące do rodziny, przyjaciół, Boga itd.) jako wystarczające dla sprostania wymogom kierowanym w stosunku do niego ze strony otoczenia. Trzeci składnik poczucia koherencji, nazwany przez Antonovsky’ego (2005) poczuciem sensowności, określany jest również mianem stopnia wysokiego poczucia sensu życia pod względem emocjonalnym. Wiąże się on z poczuciem, że warto i należy podejmować wysiłki, które - mimo że nie są łatwe - warte są zaangażowania i mają sens. Poszczególne komponenty poczucia koherencji pozostają ze sobą we wzajemnych dynamicznych związkach, tworząc złożoną i uporządkowaną całość.

Funkcjonalne właściwości poczucia koherencji ujawniają się nie tylko w obrębie zagadnień dotyczących przekonań i zachowań zdrowotnych, ale występują również na różnych płaszczyznach aktywności społecznej, rodzinnej i zawodowej, gdzie są rozpatrywane w powiązaniu z innymi czynnikami i mechanizmami regulacyjnymi. Do mechanizmów regulacyjnych zachowania jednostki należy zaliczyć m.in. wartości.

Wartości, jak podkreśla Schwartz (1992, 2006; por. Brzozowski 2007), należy traktować jako powiązane $\mathrm{z}$ emocjami przekonania. Jego zdaniem wartości: a) odnoszą się do pożądanych ostatecznych celów ludzkiej egzystencji lub zachowań, które mają charakter ponadsytuacyjny, ponieważ wykraczają poza konkretne, specyficzne sytuacje, b) kierują procesem selekcji oraz oceny zachowań i zdarzeń, c) są uporządkowane zgodnie z ich względną ważnością dla jednostek, tworząc indywidualne hierarchie wartości. Zdaniem Schwartza (1992, 2006; por. Cieciuch 2010) należy analizować nie poszczególne wartości, lecz ich typy, którymi są: 1) przystosowanie (powstrzymywanie się od działań szkodzących innym, przestrzeganie norm, samodyscyplina, posłuszeństwo, grzeczność), 2) tradycja (akceptacja nakazów i zakazów kulturowych i religijnych, skromność, poświęcenie), 3) życzliwość (troska o dobro bliskich osób, wierność, odpo- 
wiedzialność, przyjaźń, miłość), 4) uniwersalizm (troska o dobro wszystkich ludzi i środowisko, sprawiedliwość, równość, pokój, mądrość), 5) kierowanie sobą (niezależność w myśleniu i działaniu, wolność i kreatywność), 6) stymulacja (poszukiwanie nowości i urozmaicenia, śmiałość, ekscytujące życie), 7) hedonizm (dążenie do przyjemności, radość życia), 8) osiągnięcia (pragnienie osobistego sukcesu, ambicja, skuteczność), 9) władza (dążenie do kontroli, dominacji i prestiżu, autorytet, bogactwo), 10) bezpieczeństwo (zabezpieczenie dla siebie i bliskich, ład społeczny, harmonia, czystość, zdrowie, poczucie przynależności).

\section{BADANIA WŁASNE}

Celem podjętych badań było poszukiwanie zależności między poczuciem koherencji i jego wymiarami a wartościami podstawowymi u kobiet $\mathrm{z}$ anoreksją i bulimią psychiczną. Badanie miało charakter pilotażowy. Za istotne kryterium różnicujące uznano postać zaburzeń odżywiania. Główny problem badawczy zawarł się w pytaniu: czy istnieje, a jeśli tak, to jaki ma kierunek, zależność między poczuciem koherencji i jego wymiarami a wartościami podstawowymi u kobiet $\mathrm{z}$ anoreksją i bulimią psychiczną? Pytania szczegółowe zostały sformułowane następująco:

1. Czy występują, a jeśli tak, to jakie, znaczące różnice w poczuciu koherencji i jego składowych u kobiet z zaburzeniami odżywiania?

2. Czy występują, a jeśli tak, to jakie, znaczące różnice w hierarchii wartości podstawowych u kobiet $\mathrm{z}$ anoreksją i bulimią psychiczną?

$\mathrm{W}$ odniesieniu do głównego problemu badawczego sformułowano następujące założenia hipotetyczne. Istnieje zależność między poczuciem koherencji a wartościami podstawowymi u kobiet z zaburzeniami odżywiania. Zakłada się, że wymiary poczucia koherencji (zrozumiałość, zaradność, sensowność) modyfikują hierarchię wartości podstawowych u badanych kobiet. Zależność poczucia koherencji z wartościami podstawowymi kształtuje się odmiennie w grupie kobiet z anoreksją i bulimią. Podstawą dla sformułowania założeń hipotetycznych były ustalenia teoretyczne oraz analiza dotychczasowych nielicznych badań (zob. Cieciuch 2010) dotyczących zależności między analizowanymi zmiennymi.

Badaniem objęto 40 kobiet $\mathrm{z}$ rozpoznaniem anorexia nervosa (AN) oraz 40 kobiet z rozpoznaniem bulimia nervosa $(\mathrm{BN})$ według kryteriów badawczych ICD10. Kobiety z rozpoznaniem anoreksji były młodsze $(M=20,1)$ od kobiet $\mathrm{z}$ bulimią $(M=23,6)$, zaczynały chorować znacząco wcześniej $(M=16,4)$ niż chore z bulimią $(M=18,6)$, ponadto rzadziej były hospitalizowane $(M=1,8)$ w porównaniu z kobietami chorującymi na bulimię $(\mathrm{M}=2,6)$.

W badaniach wykorzystano Portretowy Kwestionariusz Wartości (PVQ-R2) Schwartza oraz Kwestionariusz Orientacji Życiowej (SOC-29) Antonovsky’ego. 
Portretowy Kwestionariusz Wartości składa się z 57 twierdzeń, z czego 52 twierdzenia odpowiadają 10 typom uniwersalnych wartości podstawowych (kierowanie sobą, stymulacja, hedonizm, osiągnięcia, władza, uniwersalizm, życzliwość, przystosowanie, tradycja i bezpieczeństwo), a 5 - wartościom duchowym (nie objęto ich badaniem). Zadaniem osoby badanej było oszacowanie stopnia podobieństwa danego opisu wartości w stosunku do siebie. Dokonuje się tego przy użyciu dziewięciostopniowej skali, gdzie np. -1 oznacza, że dana wartość jest przeciwna zasadom sterującym w życiu, 0 oznacza, że dana wartość nie jest ważna, 3 - jest ważna, 6 - jest bardzo ważna, 7 - jest najważniejsza jako zasada sterująca życiem. Portretowy Kwestionariusz Wartości w najnowszej wersji (PVQ-R2) charakteryzuje się względnie dobrą rzetelnością i wysoką trafnością czynnikową (Cieciuch 2013).

Kwestionariusz Orientacji Życiowej składa się z 29 pozycji testowych wyrażonych $\mathrm{w}$ formie zdań pytających, zaopatrzonych w 7-punktową skalę szacunkową (zakres punktacji wynosi od 1 do 7) z opisanymi krańcami. Narzędzie, oprócz ogólnego wyniku poczucia koherencji ustalanego na podstawie zliczenia punktów ze wszystkich pozycji testowych, pozwala ustalić poziom trzech jego wymiarów (poczucia zrozumiałości z 11 pozycjami testowymi, poczucia zaradności z 10 pozycjami oraz poczucia sensowności z 8 pozycjami testowymi) (Antonovsky 1993, 2005). Wersja polska Kwestionariusza Orientacji Życiowej (SOC-29) jest trafnym i rzetelnym narzędziem do badania poczucia koherencji (Pasikowski 2001).

\section{WYNIKI BADAŃ}

Pierwszy etap analiz polegał na obliczeniu średnich oraz odchyleń standardowych poczucia koherencji i jego wymiarów, a także wartości podstawowych w obu badanych grupach ${ }^{1}$. Z uwagi na to, że uzyskane wyniki odbiegały od rozkładu normalnego, do porównania wartości otrzymanych w grupach badanych kobiet wykorzystano test nieparametryczny U Manna-Whitneya. Wartości średnie oraz odchylenia standardowe poczucia koherencji i jego składowych zamieszczono w tab. 1.

Porównania dokonane między kobietami z anoreksją i bulimią wykazały istotne statystycznie różnice w natężeniu dwóch spośród czterech analizowanych komponentów poczucia koherencji. Dotyczą one ogólnego poczucia koherencji i składowej poczucia zaradności. Kobiety z anoreksją w porównaniu z kobietami z bulimią dysponują większymi zasobami odpornościowymi i możliwościami

${ }^{1}$ Wartości średnie oraz odchylenia standardowe poczucia koherencji i jego składowych u kobiet z zaburzeniami odżywiania i w grupie kontrolnej zostały zaprezentowane w artykule Związek poczucia koherencji z systemem wartości u osób z zaburzeniami odżywiania (w druku). Otrzymane rezultaty wykazały zróżnicowanie między osobami z zaburzeniami odżywiania a zdrowymi zarówno w ogólnym poczuciu koherencji, jak i we wszystkich jego komponentach. 
Tab. 1. Średnie i odchylenia standardowe poczucia koherencji i jego komponentów w grupie kobiet z anoreksją i bulimią psychiczną oraz test istotności różnic U Manna-Whitneya

\begin{tabular}{|l|c|c|c|c|c|c|}
\hline \multirow{2}{*}{\multicolumn{1}{|c|}{ SOC-29 }} & \multicolumn{2}{|c|}{ Anoreksja } & \multicolumn{2}{c|}{ Bulimia } & U & \multirow{2}{*}{$\mathrm{p}$} \\
\cline { 2 - 6 } & $\mathrm{M}$ & $\mathrm{SD}$ & $\mathrm{M}$ & $\mathrm{SD}$ & $\begin{array}{c}\text { Manna- } \\
\text { Whitneya }\end{array}$ & \\
\hline Ogólne poczucie koherencji & 3,35 & 0,57 & 3,16 & 0,74 & 516,0 & 0,0060 \\
\hline Poczucie zrozumiałości & 3,24 & 0,68 & 3,13 & 0,88 & 675,5 & 0,2320 \\
\hline Poczucie zaradności & 3,50 & 0,61 & 3,02 & 0,70 & 438,0 & 0,0004 \\
\hline Poczucie sensowności & 3,29 & 1,20 & 3,36 & 0,86 & 764,0 & 0,7340 \\
\hline
\end{tabular}

Różnice istotne statystycznie na poziomie $\mathrm{p}<0,05$

Źródło: opracowanie własne.

adaptacyjnymi oraz uruchamiają większy zakres zasobów w walce z niesprzyjającymi okolicznościami i wymaganiami życia.

Wartości średnie i odchylenia standardowe oceny 10 wartości podstawowych $^{2}$ poddanych zalecanej przez Schwartza procedurze ipsatyzacji ${ }^{3}$, zamieszczono w tab. 2.

Tab. 2. Średnie i odchylenia standardowe wartości podstawowych w grupie kobiet z anoreksją i bulimią psychiczną oraz test t istotności różnic

\begin{tabular}{|l|c|c|c|c|c|c|}
\hline \multirow{2}{*}{ Wartości } & \multicolumn{2}{|c|}{ Anoreksja } & \multicolumn{2}{c|}{ Bulimia } & \multirow{2}{*}{$\mathrm{t}$} & \multirow{2}{*}{$\mathrm{p}$} \\
\cline { 2 - 6 } & $\mathrm{M}$ & $\mathrm{SD}$ & $\mathrm{M}$ & $\mathrm{SD}$ & & \\
\hline Kierowanie sobą & 0,440 & 0,800 & 0,029 & 0,696 & 2,454 & 0,016 \\
\hline Stymulacja & $-0,316$ & 0,831 & $-0,944$ & 0,978 & 3,096 & 0,003 \\
\hline Hedonizm & $-0,950$ & 1,063 & $-0,194$ & 0,916 & $-3,403$ & 0,001 \\
\hline Osiągnięcia & 0,119 & 0,567 & $-0,317$ & 0,806 & 2,800 & 0,007 \\
\hline Władza & $-0,525$ & 0,923 & $-0,861$ & 0,988 & 1,573 & 0,120 \\
\hline Uniwersalizm & $-0,200$ & 0,471 & $-0,030$ & 0,534 & $-1,508$ & 0,135 \\
\hline
\end{tabular}

${ }^{2}$ Dane dotyczące preferencji wartości podstawowych osób z zaburzeniami odżywiania zostały omówione szczegółowo $\mathrm{w}$ artykule The hierarchy of values of people with eating disorders (Wiatrowska 2016).

${ }^{3}$ Procedura ipsatyzacji polega na przekształceniu dla każdej z osób badanych każdego ze wskaźników wartości przez odjęcie od niego średniej odpowiedzi tej osoby na wszystkie pytania kwestionariusza. Procedura minimalizuje zakłócający wpływ różnic indywidualnych. Wynik dodatni świadczy o umiejscowieniu tej wartości powyżej średniej, zaś ujemny - poniżej średniej w systemie wartości osoby lub grupy. Wartości o wskaźniku 0 zajmują środkowe miejsca w hierarchii wartości (Pilch 2012). 


\begin{tabular}{|l|c|c|c|c|c|c|}
\hline Życzliwość & 0,140 & 0,574 & 0,504 & 0,679 & $-2,587$ & 0,012 \\
\hline Przystosowanie & 0,500 & 0,863 & 0,114 & 0,764 & 2,120 & 0,037 \\
\hline Tradycja & $-0,120$ & 0,591 & $-0,652$ & 0,944 & 3,026 & 0,004 \\
\hline Bezpieczeństwo & $-0,015$ & 0,497 & 0,429 & 0,723 & $-3,199$ & 0,002 \\
\hline
\end{tabular}

Różnice istotne statystycznie na poziomie $\mathrm{p}<0,05$

Źródło: opracowanie własne.

Badane grupy kobiet różniły się istotnie w zakresie 8 (kierowanie sobą, stymulacja, hedonizm, osiągnięcia, życzliwość, przystosowanie, tradycja, bezpieczeństwo) spośród 10 wartości podstawowych. Kobiety z anoreksją, w porównaniu z kobietami z bulimią, najwyższe znaczenie nadały wartości przystosowanie. Drugą po przystosowaniu preferowaną przez kobiety z anoreksją wartością było kierowanie sobą. Najmniej preferowaną wartością $\mathrm{w}$ tej grupie okazała się stymulacja oraz hedonizm, który zajął ostatnie miejsce w hierarchii wartości. Z kolei kobiety z bulimią odróżnia od kobiet z anoreksją wyższa ocena wartości życzliwość (różnice w ocenach dotyczą siły preferencji) oraz bezpieczeństwo. Istotnie niżej ocenianymi wartościami w grupie kobiet $\mathrm{z}$ bulimią były osiągnięcia (różnica ocen dotyczy miejsca tej wartości w hierarchii), tradycja oraz stymulacja, która zajęła ostatnie miejsce $w$ ich hierarchii wartości.

W drugim etapie analiz obliczono korelacje między poczuciem koherencji i jego wymiarami a wartościami podstawowymi u kobiet $\mathrm{z}$ anoreksją i bulimią. Otrzymane wartości współczynników korelacji r Pearsona przedstawiają poniższe tabele.

Tab. 3. Współczynniki korelacji między ogólnym poczuciem koherencji a wartościami podstawowymi w grupie kobiet z anoreksją i bulimią psychiczną oraz test istotności różnic dla tych współczynników

\begin{tabular}{|l|c|c|c|}
\hline \multirow{2}{*}{ Wartości } & \multicolumn{2}{|c|}{$\begin{array}{c}\text { Współczynniki korelacji } \mathrm{r}- \\
\text { Ogólne poczucie koherencji }\end{array}$} & $\begin{array}{c}\text { Istotność różnic } \\
\text { współczynników } \\
\text { korelacji p }\end{array}$ \\
\cline { 2 - 3 } & Anoreksja & Bulimia & ni. \\
\hline Kierowanie sobą & $-0,35^{*}$ & $-0,16$ & 0,002 \\
\hline Stymulacja & $-0,12$ & $0,56^{* * *}$ & 0,007 \\
\hline Hedonizm & $-0,32^{*}$ & 0,30 & ni. \\
\hline Osiągnięcia & 0,21 & 0,30 & ni. \\
\hline Władza & $-0,12$ & 0,07 & ni. \\
\hline Uniwersalizm & 0,05 & 0,02 & \\
\hline
\end{tabular}




\begin{tabular}{|l|c|c|c|}
\hline Życzliwość & 0,11 & $-0,11$ & ni. \\
\hline Przystosowanie & 0,31 & $-0,19$ & 0,030 \\
\hline Tradycja & 0,14 & $-0,41^{* *}$ & 0,015 \\
\hline Bezpieczeństwo & 0,18 & 0,14 & ni. \\
\hline
\end{tabular}

Istotne współczynniki korelacji oznaczono: * na poziomie istotności $0,05, * *$ na poziomie istotności $0,01, * * *$ na poziomie istotności 0,$001 ;$ ni. - nieistotne statystycznie

Źródło: opracowanie własne.

Wzrost ogólnej orientacji życiowej kobiet z jadłowstrętem psychicznym wiąże się ze spadkiem preferencji wartości kierowanie sobą oraz hedonizm. W grupie kobiet z bulimią zwiększenie zasobów odpornościowych i możliwości adaptacyjnych łączy się ze wzrostem wartości stymulacja oraz spadkiem wartości tradycja. Badane grupy kobiet różnią się istotnie pod względem współczynników korelacji. Dotyczy to współzależności między ogólnym poczuciem koherencji a takimi wartościami, jak: stymulacja, hedonizm, przystosowanie i tradycja.

Tab. 4. Współczynniki korelacji między poczuciem zrozumiałości a wartościami podstawowymi w grupie kobiet z anoreksją i bulimią psychiczną oraz test istotności różnic dla tych współczynników

\begin{tabular}{|l|c|c|c|}
\hline \multirow{2}{*}{ Wartości } & \multicolumn{2}{|c|}{$\begin{array}{c}\text { Współczynniki korelacji r }- \\
\text { Poczucie zrozumiałości }\end{array}$} & $\begin{array}{c}\text { Istotność różnic } \\
\text { współczynników } \\
\text { korelacji } \mathrm{p}\end{array}$ \\
\cline { 2 - 3 } & Anoreksja & Bulimia & ni. \\
\hline Kierowanie sobą & $-0,10$ & $-0,19$ & 0,001 \\
\hline Stymulacja & $-0,18$ & $0,56^{* * *}$ & ni. \\
\hline Hedonizm & $-0,20$ & 0,12 & ni. \\
\hline Osiągnięcia & $0,43^{* *}$ & 0,13 & ni. \\
\hline Władza & 0,03 & $-0,13$ & ni. \\
\hline Uniwersalizm & $-0,05$ & 0,08 & ni. \\
\hline Życzliwość & 0,14 & $-0,11$ & ni. \\
\hline Przystosowanie & 0,10 & $-0,08$ & ni. \\
\hline Tradycja & 0,01 & $-0,25$ & ni. \\
\hline Bezpieczeństwo & $-0,14$ & 0,20 & \\
\hline
\end{tabular}

Istotne współczynniki korelacji oznaczono: * na poziomie istotności $0,05, * *$ na poziomie istotności $0,01, * * *$ na poziomie istotności 0,$001 ;$ ni. - nieistotne statystycznie

Źródło: opracowanie własne.

Poczucie zrozumiałości $\mathrm{w}$ grupie kobiet $\mathrm{z}$ anoreksją wiąże się z potrzebą osiągnięć i odnoszeniem sukcesów osobistych. W grupie kobiet $\mathrm{z}$ bulimią wzrost zdolności do rozumienia oraz poznawczej oceny rzeczywistości sprzyja natomiast 
zapotrzebowaniu na stymulację. Istotne różnice między współczynnikami korelacji w badanych grupach kobiet wystąpiły jedynie pomiędzy poczuciem zrozumiałości a wartością stymulacja.

Tab. 5. Współczynniki korelacji między poczuciem zaradności a wartościami podstawowymi w grupie kobiet z anoreksją i bulimią psychiczną oraz test istotności różnic dla tych wspólczynników

\begin{tabular}{|l|c|c|c|}
\hline \multirow{2}{*}{ Wartości } & \multicolumn{2}{|c|}{\begin{tabular}{c} 
Współczynniki korelacji r - \\
\multirow{2}{*}{ Poczucie zaradności }
\end{tabular}} & \multirow{2}{*}{$\begin{array}{c}\text { Istotność różnic } \\
\text { współczynników korelacji } \mathrm{p}\end{array}$} \\
\cline { 2 - 3 } & Anoreksja & Bulimia & ni. \\
\hline Kierowanie sobą & $-0,10$ & $-0,08$ & 0,004 \\
\hline Stymulacja & $-0,04$ & $0,57^{* * *}$ & 0,001 \\
\hline Hedonizm & $-0,34^{*}$ & $0,43^{* *}$ & 0,036 \\
\hline Osiągnięcia & $-0,12$ & $0,36^{*}$ & ni. \\
\hline Władza & 0,07 & 0,27 & ni. \\
\hline Uniwersalizm & 0,13 & 0,01 & ni. \\
\hline Życzliwość & $-0,21$ & $-0,22$ & ni. \\
\hline Przystosowanie & 0,03 & $-0,31$ & 0,028 \\
\hline Tradycja & $-0,07$ & $-0,53^{* * *}$ & ni. \\
\hline Bezpieczeństwo & $-0,10$ & 0,15 & \\
\hline
\end{tabular}

Istotne współczynniki korelacji oznaczono: * na poziomie istotności $0,05, * *$ na poziomie istotności $0,01, * * *$ na poziomie istotności 0,001 ; ni. - nieistotne statystycznie

Źródło: opracowanie własne.

Poczucie zaradności w grupie kobiet $\mathrm{z}$ anoreksją koreluje jedynie $\mathrm{z}$ wartością hedonizm. Zależność między analizowanymi zmiennymi ma charakter ujemny. Zatem wzrost poczucia zaradności wiąże się u kobiet $\mathrm{z}$ anoreksją ze spadkiem preferencji tej wartości. W grupie kobiet $\mathrm{z}$ bulimią zależność ta ma odwrotny kierunek. W tej grupie kobiet wystąpiły również inne układy zależności między poczuciem zaradności a preferowanymi wartościami. Mianowicie poczucie zaradności w tej grupie koreluje także dodatnio ze stymulacją i osiągnięciami oraz ujemnie z wartością tradycja. Kobiety z obu grup zaburzeń odżywiania różnią się istotnie pod względem współczynników korelacji. Różnice wystąpiły w stopniu zależności między poczuciem zaradności a takimi wartościami, jak: stymulacja, hedonizm, osiągnięcia i tradycja. 
Tab. 6. Współczynniki korelacji między poczuciem sensowności a wartościami podstawowymi w grupie kobiet $\mathrm{z}$ anoreksją i bulimią psychiczną oraz test istotności różnic dla tych współczynników

\begin{tabular}{|l|c|c|c|}
\hline \multirow{2}{*}{ Wartości } & \multicolumn{2}{|c|}{$\begin{array}{c}\text { Współczynniki korelacji r } \\
\text { Poczucie sensowności }\end{array}$} & $\begin{array}{c}\text { Istotność różnic } \\
\text { współczynników korelacji p }\end{array}$ \\
\cline { 2 - 3 } & Anoreksja & Bulimia & ni. \\
\hline Kierowanie sobą & $-0,46^{* *}$ & $-0,15$ & ni. \\
\hline Stymulacja & $-0,04$ & $0,38^{*}$ & 0,033 \\
\hline Hedonizm & $-0,17$ & $0,33^{*}$ & ni. \\
\hline Osiągnięcia & 0,09 & $0,38^{*}$ & ni. \\
\hline Władza & $-0,28$ & 0,12 & ni. \\
\hline Uniwersalizm & 0,04 & $-0,04$ & ni. \\
\hline Życzliwość & 0,22 & 0,04 & 0,008 \\
\hline Przystosowanie & $0,43^{* *}$ & $-0,17$ & 0,008 \\
\hline Tradycja & 0,28 & $-0,37^{*}$ & ni. \\
\hline Bezpieczeństwo & 0,08 & 0,01 & \\
\hline
\end{tabular}

Istotne współczynniki korelacji oznaczono: * na poziomie istotności $0,05, * *$ na poziomie istotności $0,01, * * *$ na poziomie istotności 0,001 ; ni. - nieistotne statystycznie

Źródło: opracowanie własne.

Wzrost poczucia sensowności w grupie kobiet z anoreksją wiąże się ze spadkiem wartości kierowanie sobą oraz ze wzrostem preferencji wartości przystosowanie. W grupie kobiet z bulimią wystąpiły natomiast inne, różniące się od siebie, układy zależności między poczuciem sensowności a preferowanymi wartościami. Poczucie sensowności w tej grupie wiąże się pozytywnie ze stymulacją, hedonizmem i osiągnięciami, negatywnie zaś z tradycją. Istotne różnice między współczynnikami korelacji dla badanych grup kobiet wystąpiły pomiędzy poczuciem sensowności a wartościami: hedonizm, przystosowanie i tradycja.

\section{DYSKUSJA WYNIKÓW I PODSUMOWANIE}

Zasadniczym celem podjętych badań było poszukiwanie zależności między poczuciem koherencji i jego wymiarami a wartościami podstawowymi u kobiet z zaburzeniami odżywiania. Uzyskane rezultaty potwierdzają zasadność dokonanego zróżnicowania badanych kobiet ze względu na postać zaburzeń odżywiania. Istotne statystycznie różnice wystąpiły zarówno w natężeniu poszczególnych zmiennych, jak i w strukturze powiązań między nimi.

Kobiety z anoreksją charakteryzuje znacząco wyższe ogólne poczucie koherencji oraz poczucie zaradności, co oznacza, że dysponują większymi niż kobiety z bulimią zasobami odpornościowymi i możliwościami adaptacyjnymi. Spostrzegają napływające bodźce w kategoriach wyzwania, a nie straty lub krzywdy, co 
implikuje bardziej przystosowawczą ocenę sytuacji trudnych i sprzyja mobilizacji dostępnych środków czy zasobów, dzięki którym mogą aktywnie wpływać na sytuacje i osiągać zamierzone cele. Wyższe poczucie koherencji u kobiet $\mathrm{z}$ anoreksją psychiczną zwiększa, jak pisze Antonovsky (2005), szansę na przesuwanie się na kontinuum w kierunku bieguna „zdrowie”, ponieważ sprzyja unikaniu zagrożeń zdrowotnych oraz zwiększa dostępność zasobów osobistych i innych w walce z niesprzyjającymi okolicznościami lub wymogami życia. $Z$ kolei niższe poczucie koherencji u kobiet z bulimią psychiczną nie służy poszukiwaniu i wykorzystywaniu adekwatnych z punktu widzenia możliwości adaptacyjnych zasobów odpornościowych. Ponadto nie sprzyja radzeniu sobie z chorobą, gdyż powoduje przekształcanie się napięcia emocjonalnego w stan stresu oraz zaostrza szkodliwe fizjologiczne skutki napięcia psychicznego. Uzyskane rezultaty pozostają rozbieżne z wynikami badań przeprowadzonych przez Salę i Simona (2011), którzy badając kobiety z anoreksją i bulimią (grupę porównawczą stanowiły kobiety z zaburzeniami nerwicowymi), nie stwierdzili różnic w natężeniu składowych poczucia koherencji w wyodrębnionych grupach. Ich zdaniem kobiety z anoreksją i bulimią psychiczną charakteryzują się zbliżonymi zasobami zdrowia, co umożliwia podjęcie efektywnej psychoterapii w warunkach heterogennej społeczności terapeutycznej.

Kobiety z anoreksją w porównaniu z kobietami z bulimią istotnie wyżej cenią takie wartości, jak np. przystosowanie, które zajęło pierwsze miejsce w hierarchii, oraz kierowanie sobą. Przystosowanie wiąże się z posłuszeństwem i samodyscypliną oraz kontrolowaniem nieakceptowanych skłonności i zachowań (zob. Schwartz 1992; por. Brzozowski 2002, Cieciuch 2013). Większa skłonność preferencyjna wartości kierowanie sobą u kobiet $\mathrm{z}$ anoreksją jest związana $\mathrm{z}$ niezależnością $\mathrm{w}$ myśleniu i działaniu, co przejawia się w sytuacji dokonywania wyborów, czynnościach eksploracyjnych oraz relacjach interpersonalnych. Preferencja tej wartości zdaniem Schwartza (1992; por. Brzozowski 2002) wywodzi się z potrzeby sprawowania kontroli nad sobą i otoczeniem oraz potrzeby kompetencji, co odpowiada charakterystyce kobiet z jadłowstrętem psychicznym (zob. Wiatrowska 2009; Wolska 1999). Kobiety z anoreksją istotnie nisko, podobnie jak kobiety z bulimią, cenią wartość stymulacja (ostatnie miejsce w hierarchii), która wiąże się z potrzebą różnorodności i służy utrzymaniu optymalnego poziomu pobudzenia, oraz wartość hedonizm (ostatnie miejsce w hierarchii), która dotyczy zaspakajania własnych organicznych potrzeb i czerpania przyjemności z życia (zob. Schwartz 1992; por. Brzozowski 2002; Cieciuch 2010). Oznacza to, że badane kobiety z zaburzeniami odżywiania nie są zorientowane na stymulację oraz czerpanie przyjemności z zaspakajania własnych pragnień i dążeń. Zajmowane przez te wartości miejsce w hierarchii może być uwarunkowane wieloma czynnikami, np. posiadaną konstytucjonalnie lub występującą w danym momencie siłą kontroli bodźców, pragnień i impulsów, związanych nie tylko 
z ciałem czy jedzeniem (por. Pilecki 2009). Kobiety z bulimią istotnie wyżej niż kobiety z anoreksją oceniają, związaną z nastawieniem prospołecznym, wartość życzliwość, która - jak wykazały prowadzone w populacji polskiej badania (zob. Cieciuch 2010; Pilch 2012; Żemojtel-Piotrowska, Baran, Piotrowski 2011) - jest najmocniej preferowana, oraz wartość bezpieczeństwo, którą należy analizować zarówno w aspekcie indywidualnym, jak i grupowym. Najniżej kobiety z bulimią preferują wartość osiągnięcia, która wiąże się ze sferą osobistych sukcesów, oraz wartość tradycja, wyrażającą się w respektowaniu i akceptacji obyczajów i idei związanych z daną kulturą czy religią (zob. Brzozowski 2002).

Przyjęte założenia hipotetyczne, dotyczące występowania zależności między poczuciem koherencji i jego wymiarami a preferencjami wartości podstawowych $\mathrm{u}$ kobiet $\mathrm{z}$ anoreksją i bulimią psychiczną, znalazły potwierdzenie $\mathrm{w}$ toku przeprowadzonych analiz. W grupie kobiet $\mathrm{z}$ anoreksją wystąpiły ujemne korelacje między ogólnym poczuciem koherencji i poczuciem zaradności a wartością hedonizm. Zatem wzrost zasobów odpornościowych i możliwości adaptacyjnych, a także umiejętność wykorzystywania dostępnych środków i zasobów w radzeniu sobie z sytuacjami trudnymi wiąże się u kobiet z anoreksją ze spadkiem zaspakajania własnych potrzeb. Ponadto wzrost poczucia koherencji wiąże się u kobiet $\mathrm{z}$ anoreksją ze spadkiem niezależności w myśleniu i działaniu (kierowanie sobą), związanej z potrzebą sukcesu i kompetencji oraz sprawowania kontroli nad sobą i otoczeniem $\mathrm{W}$ grupie kobiet $\mathrm{z}$ bulimią zależność między poczuciem zaradności a wartością hedonizm ma odwrotny kierunek, mianowicie zdolność do oceny zasobów wewnętrznych i zewnętrznych jako wystarczających, by poradzić sobie z wymaganiami każdej sytuacji i osiągnąć zamierzone cele, wiąże się ze wzrostem zaspakajania własnych, przede wszystkim organicznych potrzeb. Ogólna orientacja życiowa $\mathrm{w}$ grupie kobiet z bulimią wiąże się ze wzrostem preferencji wartości stymulacja oraz ze spadkiem preferencji wartości tradycja. Zatem wzrost zasobów odpornościowych i możliwości adaptacyjnych oraz kontroli poznawczej nad otoczeniem (zrozumiałość) wiąże się u kobiet z bulimią ze wzrostem zapotrzebowania na stymulację, poszukiwaniem nowości i wyzwań, jakie stawia życie oraz z mniejszym przywiązywaniem wagi do obyczajów i norm społeczno-kulturowych. $\mathrm{W}$ grupie kobiet $\mathrm{z}$ bulimią istotne zależności wystąpiły również między poczuciem zaradności a osiągnięciami, stymulacją i tradycją. Poczucie dysponowania przez kobiety z bulimią możliwościami radzenia sobie z wymaganiami otoczenia i aktywnego wpływania na sytuację, w której się znajdują, łączy się ze sferą osobistych sukcesów i orientacją na stymulację oraz ze spadkiem akceptacji nakazów i zakazów kulturowych i społecznych. Ostatni wymiar poczucia koherencji, określany również pod względem emocjonalno-motywacyjnym poczuciem sensu życia, wiąże się u kobiet z anoreksją ze spadkiem niezależności w myśleniu i działaniu (kierowanie sobą) oraz kontrolowaniem nieakceptowanych społecznie działań i skłonności (np. związanych z jedzeniem czy kontro- 
lowaniem wagi ciała). U kobiet z bulimią poczucie sensowności jest związane z większą skłonnością do poszukiwania nowości i wyzwań, potrzebą odnoszenia sukcesów oraz ze spadkiem akceptacji obyczajów i norm społeczno-kulturowych (np. dotyczących wyglądu czy wagi ciała).

Otrzymane rezultaty mogą stanowić podstawę do dalszych analiz teoretyczno-empirycznych zorientowanych na poszukiwanie zależności między poczuciem koherencji a systemem wartości u osób z zaburzeniami odżywiania.

\section{BIBLIOGRAFIA}

Abraham S., Llevelyn-Jones D. (2004), Bulimia i anoreksja. Zaburzenia odżywiania, Warszawa: Prószyński i S-ka.

Antonovsky A. (1993), The structure and properties of the Sense of Coherence Scale, "Social Science and Medicine", Vol. 36(6), DOI: https://doi.org/10.1016/0277-9536(93)90033-z.

Antonovsky A. (2005), Rozwikłanie tajemnicy zdrowia. Jak radzić sobie ze stresem i nie zachorować, Warszawa: Instytut Psychiatrii i Neurologii.

Brzozowski P. (2002), Uniwersalność struktury wartości: koncepcja Shaloma H. Schwartza, „Roczniki Psychologiczne", nr 5.

Brzozowski P. (2007), Wzorcowa hierarchia wartości: Polska, europejska czy uniwersalna?, Lublin: Wydawnictwo UMCS.

Cieciuch J. (2010), Nadzieja jako moderator zwiazku poczucia koherencji z preferowanymi wartościami, „Kwartalnik Naukowy”, nr 2.

Cieciuch J. (2013), Pomiar wartości w zmodyfikowanym modelu Shaloma Schwartza, „Psychologia Społeczna", t. 8, nr 1(24).

Dunajska A., Rabe-Jabłońska J. (2004), Ewolucja pogląów na temat zaburzeń obrazu ciała w jadłowstręcie psychicznym, „Psychiatria i Psychologia Kliniczna”, nr 4(2).

Kreipe R.E., Dukarm C.P. (2000), Zaburzenia łaknienia u młodzieży i starszych dzieci, „Pediatria po Dyplomie", $\mathrm{nr} 4 / 3$.

Namysłowska I. (2002), Bulimia psychiczna, [w:] A. Bilikiewicz (red.), Psychiatria, t. 2, Wrocław: Wydawnictwo Medyczne Urban \& Partner.

Pasikowski T. (2001), Kwestionariusz Poczucia Koherencji dla dorostych (SOC-29), [w:] H. Sęk, T. Pasikowski (red.), Zdrowie - stres - zasoby. O znaczeniu poczucia koherencji dla zdrowia, Poznań: Wydawnictwo Fundacji Humaniora.

Pilch I. (2012), Wartości podstawowe a preferencje ideologiczne i decyzje wyborcze w wyborach do Sejmu 2011, „Preferencje Polityczne”, nr 3.

Pilecki M.W. (2009), Psychogenne uwarunkowania bulimii psychicznej, „Przegląd Lekarski”, nr 66.

Rabe-Jabłońska J. (2003), Jadłowstręt psychiczny u dorostych kobiet, „Psychiatria Polska”, t. 37(1).

Rabe-Jabłońska J., Pawełczyk T., Żechowski C., Jarema M. (2008), Standardy leczenia zaburzeń odżywiania, „Psychiatria i Psychologia Kliniczna”, nr 8/1.

Sala P., Simon W. (2011), Nasilenie ogólnych objawów psychopatologicznych, czynników motywacyjnych oraz poczucia koherencji u chorych z rozpoznaniem anoreksji i bulimii psychicznej, „Postępy Psychiatrii i Neurologii”, nr 20(3).

Schwartz S.H. (1992), Universals in the content and structure of values: Theoretical advances and empirical tests in 20 countries, "Advances in Experimental Social Psychology", No. 25(1).

Schwartz S.H. (2006), Basic human values: Theory, measurement and applications, "Revue française de sociologie", No. 47. 
Sęk H. (2001), Salutogeneza i funkcjonowanie właściwości poczucia koherencji, [w:] H. Sęk, T. Pasikowski (red.), Zdrowie - stres - zasoby. O znaczeniu poczucia koherencji dla zdrowia, Poznań: Wydawnictwo Fundacji Humaniora.

Sołtysiak T., Sudar-Malukiewicz J. (2003), Zjawiskowe formy patologii społecznych oraz profilaktyka i resocjalizacja młodzieży, Bydgoszcz: Wydawnictwo Akademii Bydgoskiej im. Kazimierza Wielkiego.

Wiatrowska A. (2009), Jakość życia w zaburzeniach odżywiania, Lublin: Wydawnictwo UMCS.

Wiatrowska A. (2016), A hierarchy of values of people with eating disorders, „Людинознавчі студії. Серія Педагогіка", $\mathrm{nr} 3 / 35$.

Wolska M. (1999), Cechy indywidualne pacjentów z zaburzeniami odżywiania się, [w:] B. Józefik (red.), Anoreksja i bulimia psychiczna. Rozumienie i leczenie zaburzeń odżywiania się, Kraków: Wydawnictwo Uniwersytetu Jagiellońskiego.

Woronowicz B.T. (2009), Uzależnienia. Geneza, terapia, powrót do zdrowia, Poznań-Warszawa: Media Rodzina, Wydawnictwo Edukacyjne Parpamedia.

Żemojtel-Piotrowska M., Baran T., Piotrowski J. (2011), Postawy roszczeniowe a system wartości w ujęciu Shaloma Schwartza, „Psychologia Społeczna”, nr 2(17).

\section{SUMMARY}

The major purpose of the studies was to search for the relations between the sense of coherence and its dimensions on the one hand, and preferences of basic values in women with eating disorders on the other. The studies made use of the Portrait Values Questionnaire (PVQ-R2) by Schwartz and the Life Orientation Questionnaire (SOC-29) by Antonovsky. 40 women with anorexia nervosa and 40 with bulimia nervosa were included within the study, according to the criteria ICD-10. There were statistically significant differences in the sense of coherence and preference of basic values in women with anorexia and bulimia as well as in the structure of relations between them. The obtained results confirm the validity of the differentiation of the studied women due to the form of an eating disorder. The knowledge of the value system of women with eating disorders may have a significant importance in explaining the general immunity resources and adaptive possibilities.

Keywords: sense of coherence; basic values; anorexia nervosa; bulimia nervosa 